\title{
Collaboration with Suppliers and Lead Users in New Product Development and Open Innovation: Empirical Evidence from Jordanian Companies
}

\author{
Zu'bi M. F. Al-Zu'bi ${ }^{1}$ \\ ${ }^{1}$ School of Business, the University of Jordan, Amman, Jordan \\ Correspondence: Zu'bi M. F. Al-Zu'bi, FHEA, School of Business, the University of Jordan, Amman, 11942 , \\ Jordan. Tel: 962-6535-5000. E-mail: z.alzubi@ju.edu.jo
}

Received: December 31, 2015

Accepted: January 26, $2016 \quad$ Online Published: February 24, 2016

doi:10.5539/emr.v5n1p32

URL: http://dx.doi.org/10.5539/emr.v5n1p32

\begin{abstract}
This study aims to investigate the effects of collaboration with suppliers and lead users in new product development on open innovation in Jordanian manufacturing companies. Data was collected from 132 companies in two industries; machinery and electronics, and hierarchical regression analysis used to test the study hypotheses, with control variables of company age, company size, and length of relationship applied to avoid their potential bias. The results show that supplier collaboration in new product development does not significantly affect open innovation, while collaboration with lead users positively and significantly affects open innovation.
\end{abstract}

Keywords: supplier collaboration in NPD, lead users collaboration in NPD, open innovation, supply chain management, new product development, Jordan

\section{Introduction}

Open innovation has become a hot research topic in recent years. The general premise of open innovation is that the plethora of ideas outside an organization's boundaries is likely to lead to better and more commercially successful products for two main reasons. The first is that customers, suppliers, and other supply chain partners constitute a large network of sources that have the ability to exponentially increase the number of ideas that could be converted into marketable products (Chesbrough, 2003; Abdallah et al., 2016). The second is that within these three entities, there are smaller, innovative sub-groups that use their own technical skills to address new and unique problems. For example, the subset of consumers who adapt to new and innovative products are referred to as "lead users" (Von Hippel, 1986).

On the basis of this premise, there have been several research studies that have aimed to explore the processes by which various external sources can lead to better products (Lilien et al., 2002). The literature concerning the relationships between innovation and external sources is found in both the supply chain field and in research on stakeholders' influences on innovative performance. Literature regarding supply chains and external sources often explores how integration with external parties can improve the New Product Development (NPD) process (Koufteros et al., 2005). Literature on the relationship between stakeholders and innovation explores the characteristics of the various stakeholders that can improve the innovative performance of the organization (Lau et al., 2010). In this study, the objective is to expand upon the existing research by examining the effects of supplier and lead users collaboration in NPD on organizational open innovation. Additionally, the relative contribution of both supply chain parties will be tested.

This paper focuses on these two external parties because previous research and anecdotal evidence have shown they can have a profound impact on the speed of new product development (Tsinopoulos \& Al Zu'bi, 2012). However, contrary to previous research, which focused on measuring various new product development metrics, this study investigates the impact of collaboration with external parties in NPD on open innovation capability. Moreover, this paper contributes to the literature by examing such relationship in a developing country, namely Jordan. Additionally, while existing studies on open innovation have generally focused on large companies (Van de Vrande et al., 2009; Bianchi et al., 2010), the limited number of studies that focused on SMEs were conceptual or based on secondary data. Therefore, this research paper contributes to the literature by conducting 
an empirical study on open innovation based on a sample of 132 SMEs.

\section{Literature Review}

\subsection{SC Collaboration}

Supply Chain (SC) collaboration is regarded as a key pillar of Supply Chain Management (SCM; Al-Abdallah et al., 2014). Any definition of SCM will necessarily point to SC collaboration. For instance, Stock and Boyer (2009) defined SCM as "the management of a network of relationships within a firm and between interdependent organizations and business units consisting of material suppliers, purchasing, production facilities, logistics, marketing, and related systems that facilitate the forward and reverse flow of materials, services, finances and information from the original producer to final customer with the benefits of adding value, maximizing profitability through efficiencies, and achieving customer satisfaction". However, there are differing views regarding SC collaboration amongst published research. Some researchers viewed internal integration as the main driver to competitive performance (e.g., Abdallah \& Phan, 2007). Zhao et al. (2008) argued that successful internal integration fosters collaboration with SC partners. Wisner and Tan (2001) asserted that severe global competition has forced companies to consider SC collaboration that is mutually beneficial as a strategic competitive tool. One stream of published research used one construct to measure SC collaboration (e.g., Al-Abdallah et al., 2014; Rosenzweig et al., 2003) leading to unclear inferences concerning the individual contribution of supplier and customer collaboration. Another stream of research made a distinction between the upstream and downstream collaborations (e.g., Abdallah et al., 2014; Koufteros et al., 2007; Cousins \& Menguc, 2006). However, this stream of research demonstrated two main limitations. Firstly, collaboration has been viewed from a broad and general perspective encompassing practices such as communication, trust, and information sharing. Secondly, customer collaboration in most studies was viewed as a general construct that implicitly or explicitly included all customers, regardless of their relative importance to the organization. This situation may explain the failure of several studies to find a significant relationship between customer collaboration and performance dimensions (e.g., Abdallah et al., 2014, Sundram et al., 2011; Flynn et al., 2010). While collaborations with suppliers and customers are widely recognized as beneficial SC aspects, less attention was given to supplier and lead user collaboration in new product development, which will be discussed in the following sections.

\subsection{Supplier Collaboration in NPD}

The terms supplier involvement and supplier collaboration are widely used in the SCM literature. While some studies have used the two terms interchangeably, other studies make a clear distinction between them. In such literature, supplier involvement is commonly defined as referring to "the resources (capabilities, investments, information, knowledge, ideas) that suppliers provide, the tasks they carry out and the responsibilities they assume regarding the development of a part, process or service for the benefit of a buyer's current or future product development projects" (Van Echtelt et al., 2008). On the other hand, supplier collaboration is defined as "a type of cross-organizational linkage, which in addition to high levels of integration is characterized by high levels of transparency, mindfulness, and synergies in participants' interactions" (Emden et al., 2006). From those definitions, it can be noted that supplier collaboration encompasses involvement and integration and goes further beyond them.

The literature has pointed to some potential obstacles that may impede successful supplier involvement. Powerful suppliers maybe reluctant to share their knowledge and competencies with their suppliers (Johnsen, 2009). Furthermore, the buying firm may regard its suppliers as potential competitors and, thus restrict the level of knowledge sharing and collaboration (Melander, 2014). Some firms fear that their shared confidential knowledge maybe leaked to competitors through the involved suppliers (Al-Zu'bi et al., 2015). Lastly, and perhaps most importantly, only suppliers who are genuinely motivated will enter into such lengthy and sometimes unproductive collaborations (Melander, 2014).

Supplier selection is an important aspect when the purpose is to develop new innovative products (Bengtsson et al., 2013). Suppliers are usually selected on the basis of their technological or/and relational capabilities (Feng et al., 2010). Supplier experience and specialization of the needed parts and components is another important selection criterion (Melander, 2014). Furthermore, a strategic supplier collaboration requires early involvement in product development, risk sharing, commitment, supplier knowledge, and trust (Bensaou, 1999).

\subsection{Lead User Collaboration in NPD}

Lead user theory was proposed by Von Hippel (1986), who stated in general terms that the involvement of users in the product development may considerably affect the innovativeness of the product. Lead users are a specific 
subset of users: those who encounter needs today that other users may encounter only in the future.

Collaboration with lead users includes all basic principles of customer involvement and integration. Generally, customer integration is negotiated by "demand management practices through long-term customer relationship, satisfaction improvement, and complaint management" (Tan et al., 1998). The literature concerning customer integration points to the critical role of focusing on main customers by obtaining a deep understanding of their requirements and needs (Abdallah \& Matsui, 2008). The literature has also highlighted some activities that enhance customer collaboration in general. Such activities include direct contacts, customer complaints management, problem-solving teams, long-term relationships, focusing on customer satisfaction, risk sharing, and trust (Abdallah \& Matsui, 2007a; Boulding et al., 2005; Sousa, 2003). These practices greatly enhance relational capital and facilitate lead users involvement in NPD projects. In addition to accelerated NPD, research has pointed to other expected benefits of lead users collaboration such as facilitated product differentiation, ability to resolve potential problems faster, enhanced knowledge concerning existing and potential technologies, increase flexibility to respond faster to customer requirements, and increased profits and retention power of lead customers (Abdallah et al., 2009; Abdallah \& Matsui, 2007b; Al-Zu'bi, 2010; Al-Zu'bi et al., 2012). Moreover, customer collaboration increases the level and quality of information sharing. Such shared information brings additional benefits such as reduced inventories, shortened product design and operations planning time, enhanced ability of perceiving demand fluctuations more quickly, and improved innovation capability (Phan et al., 2011; Abdallah, 2013; Flynn et al., 2010; Koufteros et al., 2005). The failure to involve lead users in the NPD projects may lead to potential difficulties such as failure in commercializing the new products (Al-Zu'bi \& Tsinopoulos, 2012; Cooper, 2003).

\subsection{Open Innovation}

Open innovation is defined as "the use of purposive inflows and outflows of knowledge to accelerate internal innovation and to expand the markets for external use of innovation" (Chesbrough et al., 2006). De Jong et al. (2008) identified some major behavioural dimensions of open innovation, including: proper networking strategy that facilitates knowledge acquisition; collaboration with upstream and downstream partners to get valuable knowledge and new ideas; entrepreneurship; effective benefitting from external intellectual property by acquiring them; and steering the internal Research and Development (R\&D) to benefit from external sources.

Chesbrough (2003) summarized the main principles of traditional closed innovations and open innovations. Closed innovation is characterized by attracting smart individuals to work for the innovating company, initiating, developing, making, and commercializing innovative products by own efforts, and striving to protect intellectual property from competitors. The principles of open innovation are characterized by involving smart individuals outside the organization, under the premises that external R\&D creates new opportunities, that profitable projects could be initiated by major suppliers or customers, and that a combination of best internal and external ideas will yield the best innovation results.

Open innovation can take a number of forms, depending on how ideas are generated and exploited (Gassmann \& Enkel, 2004). The first process, "outside-in", is associated with increasing a company's innovativeness by bringing external knowledge and ideas into the company through collaboration with suppliers and customers. The second process, "inside-out", is associated with gaining profits by selling innovative ideas, intellectual property and technologies to markets. The third process, the "coupled process", is associated with combining the inside-out and outside-in processes via alliances with partners that allow effective knowledge sharing.

\section{Framework and Research Hypotheses}

\subsection{Research Framework}

The framework for this study is shown in Figure 1 below. The framework depicts the effects of supplier and lead user collaboration in NPD on open innovation. To reveal more rigorous results, the effects of three control variables - company size, company age, and length of relationship - are also considered. 
Independent variables

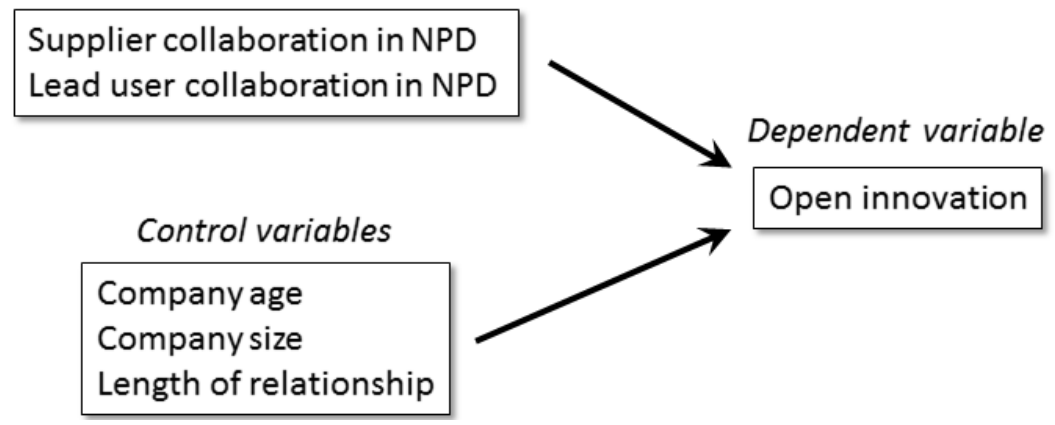

Figure 1. Research framework

\subsection{Research Hypotheses}

\subsubsection{The Effect of Supplier Collaboration in NPD on Open Innovation}

Technical knowledge capacity has the ability to encourage collaboration between suppliers and lead users, and is likely to improve the organization's innovative ability (Tsinopoulos \& Al Zu'bi, 2013). The technical knowledge that suppliers may have can provide an opportunity to re-assess the potential new ideas and make the necessary improvements starting from the research and development phases and in subsequent testing and analysis phases. Suppliers with technical knowledge are more likely to have the ability to help product development teams advance existing products and ideas. Many technical issues that may appear later in the development process and impede the progress of the project can be addressed and resolved in the early stages by the involved suppliers (Haeussler et al., 2012).

Many manufacturing companies collaborate with suppliers in order to improve operational and SC performance (Abdallah et al., 2014). Supplier involvement in new product development is expected to yield many benefits for the buying company. Melander (2014) argued that companies collaborate with suppliers in NPD in order to get access to new or advanced technology that the suppliers may have. Such technological integration may open new opportunities for the buying firm in designing and developing new products by incorporating the supplier's technology as complementary to internal technology (Takeishi, 2002). However, this will require a careful supplier selection criteria as new product performance will heavily depend on the degree on supplier involvement and selection success (Lau et al., 2010; Von Corswant \& Tunälv, 2002). Also, supplier collaboration enhances speed of NP introduction (Tsinopoulos \& Al Zu'bi, 2012) and flexibility of the new product (Abdallah $\&$ Matsui, 2009). Thus, suppliers' contribution is expected to improve functional characteristics of products under development.

Companies pursuing mass customization and modularity strategies can benefit greatly from involving their suppliers as early as the product design phase (Salvador et al., 2002). Such coordination and collaboration can increase the number of product classes offered by the buying firm (Abdallah \& Matsui, 2009), and enhance company's innovativeness by increased modularity (Abdallah \& Matsui, 2008). In such a situation, economies of scales for the buying firm and its suppliers can be achieved via the components, not the products, and economies of scope are achieved by combining the modular components into different new and innovative products (Abdallah \& Matsui, 2008; Pine, 1993). Consequently, company's exploitation and exploration ability to offer more and more new innovative products will be enhanced.

H1: Supplier collaboration in new product development will be positively related to open innovation.

\subsubsection{The Effect of Lead-Users Collaboration in NPD on Open Innovation}

Lead users possess knowledge that is relevant to an organization's products and product development (Morrison et al., 2004). Such knowledge is likely to have been acquired by an iterative process that starts with the identification of lead users needs and is followed by the creative application of suppliers' technical skills. On one hand, It has been argued that while lead users and suppliers have different incentives to be involved in NPD activities, they will have analogous technical knowledge with regard to the new products under development (Tsinopoulos \& Al Zu'bi, 2013). On the other hand, lead user theory (Von Hipplel, 1986) emphasizes that lead users, but not suppliers, can predict early new innovative products that are not perceived yet by the rest of the 
market. Such a valuable knowledge is vailable for lead users based on their deep understanding of consumer needs and requirements. This knowledge, combined with lead users' motivation to gain significant benefits from the new innovative products, provides the organization with a pool of new innovative ideas thus enhancing its open innovation capability. Furthermore, lead user collaboration in NPD represents a fast and cheap source for the organization to generate new innovative ideas (von Hippel \& Riggs, 1996). These authors further pointed to the fact that products suggested by lead users were found to be more attractive for consumers than other products. Additionally, new products suggested by lead users were found to be more cost-effectice and more functional than other products (Olson \& Bakka, 2001). The producer-lead users collaboration is seen as two-sided. Producers benefit not only by generating new innovative ideas, but by learning from lead users. Lead users will benefit by developing their preferences and needs for the future and ahead of the rest of the market (Hjalager et al., 2015). However, research have found that lead users collaboration is a confusing process that is difficult to manage and results in delayed and complicated new product development process (O'Toole \& Lynch, 2004).

$\mathrm{H} 2$ : Lead user collaboration in the new product development will be positively related to open innovation.

A third hypothesis, based on the literature review, is also proposed:

H3: Lead user collaboration in NPD will have higher impact on open innovation than to supplier collaboration.

\section{Methodology}

\subsection{Data Collection}

A questionnaire was prepared to gather data for this research. The measurement scales for the independent variables and dependent variable were adapted from literature. The respondents were asked to evaluate their agreement or disagreement with the question items using 5 point Likert scale where 5 indicated strong agreement and 1 indicated strong disagreement. The measurement scale for supplier collaboration in NPD was adapted from Abdallah (2009). The scale for lead user collaboration in NPD was adopted from Tsinopoulos and Al-Zu'bi (2012). The open innovation measurement scale was adopted from Pervan et al. (2015). Although the adopted measurement scales had exhibited high validity and reliability in the original studies, they were pilot tested with five professors in business management and revised the question items as needed. The population of this study represented all machinery and electronics manufacturing companies in Jordan. These companies are innovation oriented compared with other manufacturing sectors in Jordan. The researchers targeted 250 manufacturing companies. Visits were made personally to all companies in order to ensure a high participation rate. The targeted respondent (unit of analysis) in each company was the NPD manager. While many companies did not have such a formal position, the operations manager or production manager responsible for NPD activities was asked to complete the questionnaire. The researchers carefully explained the term "lead-users" to respondents as it was not clear to many managers. The process of data collection continued for approximately one month, and 163 questionnaires were collected. Out of the collected questionnaires, 31 were defined as unusable and were excluded. This high number of unusable questionnaires was mainly attributed to unanswered question items concerning lead users. The final number of usable questionnaires was 132, representing a response rate of $52.8 \%$. This response rate is consistent with other previous empirical studies (Obeidat et al., 2014; Suifan et al., 2015).

\subsection{Measurement Analysis}

Validity of the measurement scales is a crucial factor in empirical research (Hair et al., 2010). Content and face validity were attained by using the constructs from well-tested scales in the literature and by pilot-testing the adapted measurement scales. Construct validity was tested using Exploratory Factor Analysis (EFA, Hair et al., 2010), with the criteria that all question items for a scale loaded onto one factor, with a factor loading greater than 0.40 and eginvalue greater than 1. Additionally, Varimax rotation method was used (Hair et al., 2010). It is recommended to perform Kaiser-Meyer-Olkin (KMO) test for assessing sampling adequacy and Bartlett's test of sphericity to test for homogeneity of variances (Hair et al., 2010). The two tests were performed and the results of KMO test indicated that the statistic for all the variables exceeded 0.50, and Bartlett's test of sphericity resulted in significant statistics $(\mathrm{p}<0.05)$, and thus, EFA was considered appropriate for these measurement scales.

One item of supplier collaboration in NPD did not meet the criteria and was deleted. Two items from the lead user scale, and two items from the open innovation scale did not meet the criteria and were also deleted. Next, the reliability of the measurement scales was tested using Cronbach's $\alpha$-coefficient. All three scales showed a reliability of $\alpha \geq 0.70$ (Table 1), implying a good reliability and internal consistency (Hair et al., 2010). 
Table 1. Means, standard deviations, and Cronbach's $\alpha$-coefficient

\begin{tabular}{lllll}
\hline Variable & Mean & $\begin{array}{l}\text { Standard } \\
\text { deviation }\end{array}$ & $\begin{array}{l}\text { Cronbach's } \\
\text { a-coefficient }\end{array}$ & $\begin{array}{l}\text { Final number of } \\
\text { question items }\end{array}$ \\
\hline Supplier collaboration in NPD & 3.36 & 0.532 & 0.721 & 4 \\
Lead user collaboration in NPD & 3.77 & 0.468 & 0.810 & 6 \\
Open innovation & 3.52 & 0.493 & 0.742 & 8 \\
\hline
\end{tabular}

\subsection{Control Variables}

Manufacturing companies included in the sample differed in age and size. Older companies may have developed stable and sound processes for NPD that include suppliers and lead users. Therefore the effect of companys' age should be controlled for in order to avoid any potential influences on the levels of open innovation capability. Additionally, larger companies usually have more resources dedicated to R\&D activities, and a more innovation-driven culture, and they may therefore be more attractive for both suppliers and lead users. Company size was therefore used as a control variable. Moreover, as since this study investigates supplier and lead user collaboration in NPD, the length of the relationship may potentially affect open innovation levels in the surveyed companies. The length of relationship was included as a control variable to eliminate its potential influences on open innovation levels.

\section{Results}

Hierarchical regression analysis was used to test hypotheses H1 and H2. Prior to this analysis, normality was assessed using tests of skewness and kurtosis. The values of skewness ranged from -0.154 to 0.060 , and the kurtosis test gave values between -0.230 and -0.549 . Both tests provided evidence that the data are normally distributed and appropriate for regression analysis (Hair et al., 2010). One potential problem when using regression models is multicollinearity, which is a result of highly correlated variables, and can lead to unreliable results in regression analysis (Hair et al., 2010). The Variance Inflation Factor (VIF) technique was applied to ensure that the results were not affected by this problem. The VIF values for the independent variables were below 1.3 , indicating that multicollinearity was not a concern in this analysis.

Two steps of hierarchical regression analysis were used. In the first step, the control variables alone were entered. In the second step, the independent variables were added to the control variables. The first step revealed that control variables alone did not contribute significantly to the variation in the dependent variable (Adj. $R^{2}=$ $0.032, p>0.05)$. The second step showed that the addition of the independent variables led to a significant contribution to open innovation levels (Table 2; Adj. $R^{2}=0.189, p<0.01$ ). Regarding the individual effects of the independent variables on open innovation, the results showed that supplier collaboration in NPD did not significantly affect open innovation $(\beta=0.072 ; p>0.05)$. Lead user collaboration in NPD, on the other hand, showed a positive and significant effect on open innovation $(\beta=0.395 ; p<0.01)$. Based on these results, hypothesis $\mathrm{H} 1$ is rejected and hypothesis $\mathrm{H} 2$ is accepted. Additionally, the results apparently supported H3 concerning the relative contribution of the independent variables on open innovation. Lead user collaboration in NPD is highly significantly related to open innovation while supplier collaboration in NPD is insignificantly related to NPD. To ensure that the difference between the coefficients is significant, the Wald test was conducted. The results of this test confirmed the conclusion and hypothesis H3 is accepted. 
Table 2. Hierarchical regression analysis of open innovation

\begin{tabular}{lll}
\hline Variables & Step 1 & Step 2 \\
\hline (Constant) & $2.958^{* * *}$ & -0.804 \\
\hline Control variables & & \\
Company size (number of employees) & $-0.198-$ & -0.306 \\
Company age & 0.089 & 0.083 \\
Length of relationship & 0.095 & -0.065 \\
\hline Independent variables & & \\
Supplier collaboration in OI & - & 0.072 \\
Lead user collaboration in OI & - & $0.395^{* * *}$ \\
\hline$R^{2}$ & 0.067 & 0.237 \\
Adj. $R^{2}$ & 0.032 & 0.189 \\
F & & $4.915^{* * *}$ \\
$R^{2}$ change & 0.067 & 0.170 \\
F change & 1.938 & $8.820^{* * *}$ \\
\hline
\end{tabular}

$* * * p \leq 0.01$

\section{Discussion and Conclusions}

The aim of this work was to contribute to previous empirical and theoretical work that compared the relative contribution of suppliers and lead users collaboration in NPD on open innovation in manufacturing companies. Lead user collaboration in NPD was found to contribute to highly improved open innovation levels. Supplier collaboration in NPD, on the other hand, did not significantly contribute to open innovation in Jordanian manufacturing companies. Furthermore, the results confirmed the initial theoretical argument by finding that collaboration with lead users has a higher impact on open innovation than supplier's collaboration.

The result that supplier collaboration in NPD did not affect open innovation might appear surprising. There is general agreement in the literature that supplier collaboration and integration positively affect company's overall performance. Previous empirical studies confirmed such positive effect (e.g., Abdallah et al., 2014; Flynn et al., 2010). This result can be justified by at least three arguments. Firstly, Jordanian manufacturing companies rely heavily on international suppliers due to the lack of capable local suppliers with the required technical expertise and knowledge. Most raw materials and parts are imported from foreign suppliers, which makes it difficult to effectively collaborate with those suppliers. Secondly, open innovation relies on capturing and exploiting new ideas before the rest of the market. This will require deep knowledge of the market trends and requirements. Suppliers often lack such knowledge, compared with lead users, who can be regarded as valuable source of new innovative ideas. Thirdly, effective supplier collaboration in NPD comes as a result of long-term relationships and integration, based on trust, commitment, and risk-reward sharing. Most manufacturing companies in Jordan are classified as SMEs, which struggle to survive in the current highly competitive environment. Such a situation forces most companies to focus on short-term goals and profits, resulting in frequent shifts from supplier to supplier in the search of lower costs or better payment conditions. These factors impede effective supplier collaboration in NPD and inhibits the expected benefits of such collaboration. This does not mean that manufacturing companies should not collaborate with suppliers in NPD, nor can it be claimed that such collaboration would not be beneficial. However, for this sample from Jordanian manufacturing companies, these results showed that supplier collaboration did not affect open innovation capability.

Lead user collaboration in NPD proved to be highly related to open innovation levels. Companies improve their innovation abilities by integrating lead users who are a valuable source of innovation due to their unique needs and their ability to be predict creative products in an unpredictable times for the manufacturing companies based on their direct interaction with the markets. This finding has an important implication that should enable companies to focus their efforts to develop new products and improve innovation capabilities.

From this work, the recommendation to managers and manufacturing companies is to attempt to strengthen their innovative ability by integrating lead users in the new product development process. Additionally, it is 
recommended that integration with lead users should become a policy that aims at identifying a pool of individuals whose ideas and needs are integrated into the process. The challenge associated with lead user integration into the new development process, however, is the unpredictability of their innovative behaviour.

One limitation of the current study is the reliance on a single respondent from each manufacturing company. Although this method of data collection is widely used in operations and supply chain research, it could have caused common method bias. Multiple respondents from each company could, in future, reduce the bias effect. Future studies could be conducted with multiple respondents to confirm the absence of common method bias. Another limitation is that the sample included manufacturing companies from only two sectors, machinery and electronics, which could affect the generalizability of these results. Future studies are needed with companies from different industries to enable further generalization. Finally, the sample size was limited to only 132 companies. While several previous studies from both developed and developing countries have had similar sample sizes, it is preferable to have larger samples so that confirmatory factor analysis and structural equation modelling techniques could be applied.

\section{References}

Abdallah, A., \& Matsui, Y. (2007a). Just In Time Production and Total Productive Maintenance: Their Relationship and Impact on JIT and Competitive Performances. In Proceedings of the 9th International Decision Sciences Institute Conference. Bangkok, Thailand. http://dx.doi.org/10.13140/2.1.4925.9846

Abdallah, A. B., \& Matsui, Y. (2007b). The relationship between JIT production and manufacturing strategy and their impact on JIT performance. In Proceedings of the 18th Annual Production and Operations Management Society (POMS) Conference. Dallas, USA.

Abdallah, A., \& Phan, C. A. (2007). The Relationship between Just-In-Time Production and Human Resource Management, and Their Impact on Competitive Performance. Yokohama Business Review, 28(2), 27-57.

Abdallah, A., \& Matsui, Y. (2008). Customer Involvement, Modularization of Products, and Mass Customization: Their Relationship and Impact on Value to Customer and Competitiveness. In Proceedings of the Third World Conference on Production and Operations Management. Tokyo, Japan. http://dx.doi.org/ $10.13140 / 2.1 .2632 .2246$

Abdallah, A., \& Matsui, Y. (2009). The Impact of Lean Practices on Mass Customization and Competitive Performance of Mass-Customizing Plants. In Proceedings of the 20th Annual Production and Operations Management Society (POMS) Conference. Orlando, USA. http://dx.doi.org/10.13140/2.1.2445.8563

Abdallah, A. B., Phan, A. C., \& Matsui, Y. (2009). In Investigating the Relationship between Strategic Manufacturing Goals and Mass Customization. Proceedings of the 16th International Annual European Operations Management Association (EurOMA). Goteborg, Sweden. http://dx.doi.org/10.13140/ 2.1.4404.8160

Abdallah, A. B. (2009). Just-in-time production, supporting practices, and mass customization: Their relationships and impact on competitive performance (Unpublished doctoral dissertation). Yokohama National University, Japan.

Abdallah, A. B. (2013). The Influence of "Soft" and "Hard" Total Quality Management (TQM) Practices on Total Productive Maintenance (TPM) in Jordanian Manufacturing Companies. International Journal of Business and Management, 8(21), 1-13. http://dx.doi.org/10.5539/ijbm.v8n21p1

Abdallah, A. B., Obeidat, B. Y., \& Aqqad, N. O. (2014). The Impact of Supply Chain Management Practices on Supply Chain Performance in Jordan: The Moderating Effect of Competitive Intensity. International Business Research, 7(3), 13-27. http://dx.doi.org/10.5539/ibr.v7n3p13

Abdallah, A. B., Anh, P. C., \& Matsui, Y. (2016). Investigating the effects of managerial and technological innovations on operational performance and customer satisfaction of manufacturing companies. International Journal of Business Innovation and Research, 10(2/3), 153-183.

Al-Abdallah, G. M., Abdallah, A. B., \& Bany Hamdan, K. (2014). The Impact of Supplier Relationship Management on Competitive Performance of Manufacturing Firms. International Journal of Business and Management, 9(2), 192-202. http://dx.doi.org/10.5539/ijbm.v9n2p192

Al-Zu'bi, Z. b. M. F., \& Tsinopoulos, C. (2012). Suppliers versus Lead Users: Examining Their Relative Impact on Product Variety. Journal of Product Innovation Management, 29(4), 667-680. http://dx.doi.org/10.1111/j.1540-5885.2012.00932.x 
Al-Zu'bi, Z. M. F., Tarawneh, E., Abdallah, A. B., \& Fidawi, M. (2015). Investigating Supply Chain Integration Effects on Environmental Performance in the Jordanian Food Industry. American Journal of Operations Research, 5(4), 247-257. http://dx.doi.org/10.4236/ajor.2015.54019

Al-Zu'bi, Z. M. F. (2010). Collaboration in Mass Customisation: Exploring the impacts of suppliers and lead users (1st ed.). VDM Verlag, Germany.

Al-Zu'bi, Z. M. F., Al-Lozi, M., Dahiyat, S., Alshurideh, M., \& Al Majali, A. (2012). Examining the Effect of Quality Management Practices on Product Variety. European Journal of Economics, Finance and Administrative Sciences, 1, 1-19.

Al-Zu'bi, Z. M. F., \& Tsinopoulos, C. (2012). An Outsourcing Model for Lead Users: An Empirical $\begin{array}{lllll}\text { Investigation. Production Planning and } & \text { Control, } & \text { 24(4/5), } & \text { 1-10. }\end{array}$ http://dx.doi.org/10.1080/09537287.2011.648485

Bengtsson, L., Lakemond, N., \& Dabhilkar, M. (2013). Exploiting supplier innovativeness through knowledge integration. International Journal of Technology Management, 61(3), 237-253. http://dx.doi.org/10.1504/IJTM.2013.052669

Bensaou, M. (1999). Portfolios of buyer-supplier relationships. Sloan management review, 40(4), 35-44.

Bianchi, M., Campodall'Orto, S., Frattini, F., \& Vercesi, P. (2010). Enabling open innovation in small-and medium-sized enterprises: How to find alternative applications for your technologies. $R \& D$ Management, 40(4), 414-431. http://dx.doi.org/10.1111/j.1467-9310.2010.00613.x

Boulding, W., Staelin, R., Ehret, M., \& Johnston, W. (2005). A CRM Roadmap: What We Know, Potential Pitfalls, and Where to Go. Journal of Marketing, 69(4), 155-167. http://dx.doi.org/10.1509/jmkg.2005.69.4.155

Chesbrough, H. W. (2003). Open Innovation: The New Imperative for Creating and Profiting from Technology. Harvard Business School Press.

Chesbrough, H. (2003). The Era of Open Innovation. MIT Sloan management Review, 44(3), 34-41.

Chesbrough, H., Vanhaverbeke, W., \& West, J. (Eds.). (2006). Open innovation: Researching a new paradigm. Oxford: Oxford University Press.

Cooper, R. G. (2003). Profitable product innovation: The critical success factors. In L. V. Shavinina (Ed.), The International Handbook on Innovation (pp. 139-157). Elsevier Science. http://dx.doi.org/10.1016/b978-008044198-6/50010-3

Cousins, P. D., \& Menguc, B. (2006). The implications of socialization and integration in supply chain $\begin{array}{llll}\text { management. Journal of } & \text { Operations }\end{array}$ http://dx.doi.org/10.1016/j.jom.2005.09.001

De Jong, J. P. J., Vanhaverbeke, W., Kalvet, T., \& Chesbrough, H. (2008). Policies for Open Innovation: Theory, Framework and Cases. Helsinki: VISION Era-Net.

Emden, Z., Calantone, R. J., \& Droge, C. (2006). Collaborating for new product development: Selecting the partner with maximum potential to create value. Journal of Product Innovation Management, 23(4), 330-341. http://dx.doi.org/10.1111/j.1540-5885.2006.00205.x

Feng, B., Fan, Z. P., \& Ma, J. (2010). A method for partner selection of codevelopment alliances using individual and collaborative utilities. International Journal of Production Economics, 124(1), 159-170. http://dx.doi.org/10.1016/j.ijpe.2009.10.019

Flynn, B. B., Huo, B., \& Zhao, X. (2010). The impact of supply chain integration on performance: A contingency and configuration approach. Journal of Operations Management, 28(1), 58-71. http://dx.doi.org/10.1016/j.jom.2009.06.001

Gassmann, O., \& Enkel, E. (2004). Towards a Theory of Open Innovation: Three Core Process Archetypes. Mimeo, Institute of Technology Management, University of St. Gallen, Switzerland.

Haeussler, C., Patzelt, H., \& Zahra, S. (2012). Strategic alliances and product development in high technology new firms: The moderating effect of technological capabilities. Journal of Business Venturing, 27(2), 217-233. http://dx.doi.org/10.1016/j.jbusvent.2010.10.002

Hair, J. R., Black, J. F., Babin, B. J., \& Anderson, R. E. (2010). Multivariate data analysis (7th ed.). Macmillan, New York. 
Hjalager, A. M., Johansen, P. H., \& Rasmussen, B. (2015). Informing regional food innovation through lead user experiments. British Food Journal, 117(11), 2706-2723. http://dx.doi.org/10.1108/BFJ-03-2015-0098

Johnsen, T. E. (2009). Supplier involvement in new product development and innovation: Taking stock and looking to the future. Journal of Purchasing and Supply Management, 15(3), 187-197. http://dx.doi.org/10.1016/j.pursup.2009.03.008

Koufteros, X., Vonderembse, M., \& Jayaram, J. (2005). Internal and External Integration for Product Development: The Contingency Effects of Uncertainty, Equivocality, and Platform Strategy. Decision Sciences, 36(1), 97-133. http://dx.doi.org/10.1111/j.1540-5915.2005.00067.x

Koufteros, X. A., Cheng, T. C. E., \& Lai, K. H. (2007). Black-box and gray box supplier integration in product development: Antecedents, consequences and the moderating role of firm size. Journal of Operations Management, 25(4), 847-870. http://dx.doi.org/10.1016/j.jom.2006.10.009

Lau, A. K. W., Tang, E., \& Yam, R. (2010). Effects of Supplier and Customer Integration on Product Innovation and Performance: Empirical Evidence in Hong Kong Manufacturers. Journal of Product Innovation Management, 27(5), 761-777. http://dx.doi.org/10.1111/j.1540-5885.2010.00749.x

Lilien, G. L., Morrison, P., Searls, K., Sonnack, M., \& von Hippel, E. (2002). Performance assessment of the lead user idea-generation process for new product development. Management Science, 48(8), 1042-1059. http://dx.doi.org/10.1287/mnsc.48.8.1042.171

Melander, L. (2014). Buyer-Supplier Collaboration in New Product Development between Two Equally Powerful Firms: A Case Study of ABB and SKF. Operations and Supply Chain Management, 7(3), 107-113.

Morrison, P. D., \& Roberts, J. H. (2004). The Nature of Lead Users and Measurement of Leading Edge Status. Research Policy, 33(2), 351-362. http://dx.doi.org/10.1016/j.respol.2003.09.007

Obeidat, B. Y., Masa'deh, R. M., \& Abdallah, A. B. (2014). The Relationships among Human Resource Management Practices, Organizational Commitment, and Knowledge Management Processes: A Structural Equation Modeling Approach. International Journal of Business and Management, 9(3), 9-26. http://dx.doi.org/10.5539/ijbm.v9n3p9

O'Toole, T., \& Lynch, P. (2004). A study of the practice of user involvement in the early stages of new product development. Paper presented at the 11th International Product Development Conference. Dublin.

Olson, E. L., \& Bakka, G. (2001). Implementing the lead user method in a high technology firm: A longitudinal study of intentions versus actions. Journal of Product Innovation Management, 18(6), 388-395. http://dx.doi.org/10.1111/1540-5885.1860388

Pervan, S., Al-Ansaari, Y., \& Xu, J. (2015). Environmental determinants of open innovation in Dubai SMEs. Industrial Marketing Management, 50(1), 60-68. http://dx.doi.org/10.1016/j.indmarman.2015.05.029

Phan, A. C., Abdallah, A. B., \& Matsui, Y. (2011). Quality Management Practices and Competitive Performance: Empirical Evidence from Japanese Manufacturing Companies. International Journal of Production Economics, 133(2), 518-529. http://dx.doi.org/10.1016/j.ijpe.2011.01.024

Pine, B. J., Victor, B., \& Boynton, A. C. (1993). Making Mass Customization Work. Harvard Business Review, 108-119.

Rosenzweig, E. D., Roth, A. V., \& Dean Jr., J. W. (2003). The influence of an integration strategy on competitive capabilities and business performance: An exploratory study of consumer products manufacturers. Journal of Operations Management, 21(4), 437-456. http://dx.doi.org/10.1016/S0272-6963(03)00037-8

Salvador, F., Forza, C., \& Rungtusanatham, M. (2002). How to mass customize: Product architectures, sourcing configurations. Business Horizons, 45(3), 61-69. http://dx.doi.org/10.1016/S0007-6813(02)00228-8

Suifan, T. S., Abdallah, A. B., \& Sweis, R. J. (2015). The Effect of a Manager's Emotional Intelligence on Employees' Work Outcomes in the Insurance Industry in Jordan. International Business Research, 8(9), 67-82. http://dx.doi.org/10.5539/ibr.v8n9p67

Sousa, R. (2003). Linking quality management to manufacturing strategy: An empirical investigation of customer focus practices. Journal of Operations Management, 21(1), 1-18. http://dx.doi.org/10.1016/S0272-696302)00055-4

Sundram, V. P., Ibrahim, A. R., \& Govindaraju, V. G. R. (2011). Supply chain management practices in the electronics industry in Malaysia: Consequences for supply chain performance. Benchmarking: An 
International Journal, 18(6), 834-855. http://dx.doi.org/10.1108/14635771111180725

Takeishi, A. (2002). Knowledge partitioning in the interfirm division of labor: The case of automotive product development. Organization Science, 13(3), 321-338. http://dx.doi.org/10.1287/orsc.13.3.321.2779

Tan, K. C., Kannan, V. R., \& Handfield, R. B. (1998). Supply chain management: Supplier performance and firm performance. International Journal of Purchasing and Materials Management, 34(3), 2-9.

Tsinopoulos, C., \& Al Zu'bi, Z. (2012). Clockspeed Effectiveness of Lead Users and Product Experts. International Journal of Operations \& Production Management, 32(9), 1097-1118. http://dx.doi.org/10.1108/01443571211265710

Tsinopoulos, C., \& Al Zu'bi, Z. (2013). Lead users, suppliers, and experts: The exploration and exploitation trade-off in product development. International Journal of Technology Marketing, 9(1), 6-20. http://dx.doi.org/10.1504/IJTMKT.2014.058080

van de Vrande, V., De Jong, J. P., Vanhaverbeke, W., \& De Rochemont, M. (2009). Open innovation in SMEs: Trends, motives and management challenges. Technovation, 29(6), 423-437. http://dx.doi.org/10.1016/j.technovation.2008.10.001

van Echtelt, F., Wynstra, F., van Weele, A., \& Duysters, G. (2008). Managing Supplier Involvement in New Product Development: A Multiple Case Study. Journal of Product Innovation Management, 25(2), 180-201. http://dx.doi.org/10.1111/j.1540-5885.2008.00293.x

Von Hippel, E. (1986). Lead Users: A Source of Novel Product Concepts. Management Science, 32(7), 791-805. http://dx.doi.org/10.1287/mnsc.32.7.791

von Corswant, F., \& Tunälv, C. (2002). Coordinating customers and proactive suppliers a case study of supplier collaboration in product development. J. Eng. Technol. Manage., 19(1), 249-261. http://dx.doi.org/10.1016/S0923-4748(02)00020-6

von Hippel, E., \& Riggs, W. (1996). A lead user study of electronic home banking services: Lessons from the learning curve. PDMA Annual Meeting Proceedings, 145-154.

Wisner, J. D., \& Tan, K. C. (2000). Supply chain management and its impact on purchasing. Journal of Supply Chain Management, 36(4), 33-42. http://dx.doi.org/10.1111/j.1745-493X.2000.tb00084.X

Zhao, X., Huo, B., Flynn, B. B., \& Yeung, J. (2008). The impact of power and relationship commitment on the integration between manufacturers and customers in a supply chain. Journal of Operations Management, 26(3), 368-388. http://dx.doi.org/10.1016/j.jom.2007.08.002

\section{Copyrights}

Copyright for this article is retained by the author(s), with first publication rights granted to the journal.

This is an open-access article distributed under the terms and conditions of the Creative Commons Attribution license (http://creativecommons.org/licenses/by/3.0/). 